\title{
Towards a Non - Anthropocentric Paradigm: A Study of Select Narratives
}

\author{
AmrithaVydoori S P \\ Research Scholar, Deptt. of English, University of Calicut
}

\begin{abstract}
:
Enthroning human being at the centre stage of the universe gathered momentum with the emergence of humanism. This human centeredness later on gave way to a more anthropological term, viz.: anthropocentrism which considers Man as the Supreme Being. The anthropocentric point of view has created an ecological imbalance on our Earth. To ensure a harmonious coexistence of human beings and animals it is imperative to go beyond the narrow anthropocentric paradigms. A non-anthropocentric view which gives space, accepts and acknowledges the differences of other beings is to be developed. The present paper attempts to make a study of Daniel Defoe's Robinson Crusoe, Life of Pi directed by Ang Lee and Instinct by Jon Turteltaub to focus on the basic precepts of humanism, anthropocentrism and non-anthropocentrism in the select narratives.
\end{abstract}

Reference to this paper should be made as follows:

AmrithaVydoori S P,

Towards a NonAnthropocentric Paradigm: A Study of Select Narratives,

Notions 2018, Vol. IX, No.2, pp. 34-41, Article No. 6

Online available at : http://anubooks.com/ ?page_id=34

Keywords: humanism, anthropocentrism, nonanthropocentrism, paradigm. 
Enthroning human being at the centre stage of the universe gathered momentum with the emergence of humanism. Humanism looks into science instead of religious dogma in order to understand the world. It upholds freedom of the individual and insists on the idea that all human beings have the potential to lead an independent life.The well acclaimed eulogy of man in Shakespeare"sHamlet "What a piece of work is a man! How noble in reason! Howinfinite in faculty! " (Act II Scene II)captures the core of humanism and adorns him as the paragon of animals. Bertrand Russell in a lecture Why I Am Not a Christian(1927) implores the human beings to conquer the world by intelligence and underscores the power of science and its potential to make us stand upon our own feet and to look to our own efforts to make this world a fit place to live in.

Humanism encourages us to feel that, no matter who we are, we have untapped abilities, unknown potentialities, and more strength, inventiveness, and capacity for survival and progress than we know.Humanistic thought lays emphasis on the evolutionary and pragmatic character of human knowledge and ethics. Human relationships and interactions are of paramount importance in this approach.

The Swiss historian Jacob Burckhardt in The Civilization of the Renaissance in Italy saw in Renaissance the emergence of the modern spirit of individuality, which the Middle Ages had stifled. The medieval period is frequently caricatured as a time of ignorance and superstition that placed the word of religious authorities over personal experience and rational activity.Enlightenment scholars saw reason as superior to faith and disregarded the coercive power of the church.

The importance that the individual assumes in Western philosophy starting from authors such as Descartes and Locke owes much to the humanistic emphasis on the centrality of human reason in the universe. Aristotelian cosmology proposed "an earth centered finite universe wherein humans were differentiated from and seen as superior to, animals and plants by virtue of their rationality" (Merchant 142). Later, the human centeredness in humanism gave rise to a more anthropological term, viz.: anthropocentrism. Anthropocentrism privileges humans as the center of the world and positions them as the core of meaning, value, knowledge, and action. As an ideology, it functions to maintain the centrality and priority of human existence through the marginalization and subordination of other living beings.

Francis Bacon and Rene Descartes, the leading philosophical spokesmen for the scientific revolution were all strongly influenced by the Christian anthropocentric theology which privileged humans above all other living beings. Bacon claimed that modern science would allow humans to regain a command over nature, which had 
been lost with Adam's fall in the garden. Descartes, considered to be the father of modern Western philosophy, argued that the new science would make humans the masters and possessors of nature.His famous "mind-body dualism" resulted in the view that only humans had minds (or souls): all other creatures were merely bodies (machines); they had no sentience (mental life) and as a result could feel no pain. And so, in the middle of the $19^{\text {th }}$ century Darwin had to argue, against prevailing opinion, that at least the great apes experienced various feelings and emotions (Merchant 143).

The central position or supremacy bestowed upon the humans began to be questioned with the development of modern theoretical science. The Aristotelian cosmology was replaced by the original non-anthropocentric cosmological worldview. Ecology as the "subversive science" stepped across anthropocentric threshold, and implied an eco-centric orientation to the world.

Baruch Spinoza, the Dutch philosopher developed a non-anthropocentric philosophic system which provided an intellectual opportunity for western culture to abandon anthropocentrism. He attempted to re-sanctify the world by identifying god with nature. Unlike Descartes, Spinoza found mind (or mental attribute) throughout nature. Through criticism of Descartes, Spinoza developed a philosophy that would channel the new scientific understanding of nature primarily into spiritual human self-realization and into an appreciation of God/nature rather than into the misguided attempt to dominate and control nature. Spinoza's system is a fruitful guide to ecological understanding and self-realization and provides a pantheistic vision. At the beginning of the twentieth century, Harvard University philosopher George Santayana grew increasingly disillusioned with the anthropocentric pragmatist and idealist views of the time, and looked forward to an eco-centric revolution in philosophy.

The shift in the ideological perspectives relating to the position of human and non-human beings on earth is reflected in literature and films. The present paper makes an attempt to study Daniel Defoe's The Life and Strange Surprising Adventures of Robinson Crusoewhich upheld human centeredness andtwo films Life of Pi and Instinct which focus on anthropocentrism and non- anthropocentrism with a view to emphasize the need to move beyond anthropocentrism to ensure a harmonious life for all living beings on earth.

The predominant features of Renaissance Humanismsuch as the indomitable spirit of optimism, zest for discovering new lands and thirst for knowledge and adventure were reflected in the fictional works of great writers of the period. Writers like Daniel Defoe were excited by stories of sea farers surviving alone on uninhabited islands. His novel, Robinson Crusoe published in 1719 focuses on the Enlightenment 
concepts of economic individualism, colonialism and imperialismand examines how an individual left alone in an uninhabited island develops the capabilities for survival by tapping the minimum available resources and enthrones himself as the self-made king of the island.

Crusoe, the protagonist of the novel is an embodiment of humanism. Materialistic to the core, he intends to make as much profit as possible by engaging himself in travelling and trading. He relished independence and upheld the principles of individualism. The fundamental tendency of economic individualism prevents Crusoe from paying much heed to the ties of family and he opts for a life of travel and adventure. Along with some planters, Crusoe sails to the Guinea Coast in search of quicker ways to become rich. But a storm takes them to unknown areas and they wander through the sea for about twelve days. Eventually the ship struck a sandbank; the stop was so sudden that the sea at once broke over the ship. Huge waves overturned the ship and they were immediately separated from one another. Crusoe was stranded on the strange island where he was beset with two powerful fears: "of perishing with hunger or being devoured by wild beasts". Traces of imperialism and anthropocentrism crop up in him and he tries to conquer and colonize the island.A typical anthropocentric colonizer, he goes for hunting and shoots down birds without stopping to know whether their flesh is edible or not.He exploits all the resources of the island for his personal benefit. The gap of human companionship is filled by taming animals like goats, cats, dog and parrot. The complacency of Robinson Crusoe was shaken with the arrival of cannibals. He saves the life of one of the captives from the cannibals and names him Friday to commemorate the day of his rescue.Crusoe's lessons to Friday and his attempts to civilize him by teaching him western ways of life is regarded as a prelude to colonialism

After twenty eight years of life in the island both Crusoe and Friday were saved in a ship and brought to England. The study reveals that the humanistic ideals of self-reliance, individuality, reasoning power and farsightedness can work in unison to help a person to survive on an uninhabited island. Robinson Crusoe, the protagonist of the novel is represented as the dominator of the island and his conquest of the island becomes complete when he proclaims himself as its supreme ruler.

The advent of humanism relegates all the other living beings on the Earth to a marginalized position and they are deprived of their right to live. While those who are anthropocentric welcome developmental activities, the non-anthropocentric group, especially the environmental activists raise their voice against the ruthless attack on nature, its fauna and flora. To educate the public on the need to protect the vanishing species and to make them aware that Earth is a place meant for all living beings, 
various strategies have been formulated by lovers of nature. As film has developed into a suitable media to propagate ideologies easily among the public, it has been fruitfully used to awaken them to the dire necessity of protecting nature.

The basic precepts of humanism, anthropocentrism and non-anthropocentrism converge in the two films selected for the study. Yan Martel's award-winning novel Life of $P i$ and the film rendering of it by Ang Lee serves as a typical example of this convergence. The film Life of $P i$ shows how a human being left alone in the midst of a turbulent sea in a life boat with carnivorous animals learns to survive by fighting against odd situations. The Film Instinct advocates the need for the coexistence of human beings and animals. Both films are examined from anthropocentric and nonanthropocentric perspectives.

$\mathrm{Pi}$, the protagonist of Life of $\mathrm{Pi}$, assimilates various ways of life from his surroundings and society which proves to be useful to him at different stages of his life. The lessons that he has learned from Appa, Mamaji andmother helped him to face the stark realities of life boldly. The real training that Pi got from his family and the great deal of freedom and the encouragement that he received from his mother instill confidence in him and readies him to be more independent in his later struggle for survival when he is left alone at the mercy of the turbulent sea and the ferocious beast.

Pi is an unusual child who looks at life differently. Unlike other children of his age he is curious to know the mystery of the universe, the depth of God's love, the meaning of life and truth in religion. He develops respect for all religions when he realizes that the ultimate goal of all religion is to disseminate love. He learns to love the fauna and flora and extends his sympathy and compassion towards all living creatures. The film exemplifies him as a true spokesperson of non-anthropocentrism.

Pi's father, a zoo keeper looks upon animals from an anthropocentric perspective. To him they are just tools or machines for making money and when this fails at his homeland he resolves to dismantle the zoo to move on to Canada with the zoo animals in search of better prospects. His action is at par with Rene Descartes' famous "mind-body dualism' which held the view that "only humans had minds (or souls); all other creatures were merely bodies (machines)" (Merchant 143).

Unlike his father, Pi develops a close affinity with the animals and observes their habits and behavior. His attempt to tame the animals with food is thwarted by his father who warns him "He is an animal, not your playmate", to which Pi answers "animals have souls. I have seen it in their eyes". The insight to give equal status to human and non-human world is reflected in his words. 
Pi loses his family during the journey to Canada when the Japanese ship with nearly 200 passengers encounters a shipwreck. He was left alone with some of their zoo animals: zebra, hyena and a tiger in the lifeboat. The animals fight with each other and get killed. Pi has no other living being for company except the Tiger, nicknamed as Richard Parker. At the risk of his own life he keeps away from killing the tiger as he identifies himself with it. This identification of oneself with the other living beings is the core of deep ecology. Such a world view will help in re-forming the Earth. He accepts and acknowledges the difference of the wild animals and understands that they could live together in harmony by coming to a kind of mutual understanding. He demarcates the territory for each one of them and gives space for the wild animals rather than trying to occupy and conquer the whole space solely for him. He doesn't consider himself as a supreme being, instead believes that the world belongs to all living beings. Pi sees the human and the animal kinds as connected but separate worlds, and realizes that though the animals can be tamed, they can never be expected to be as humans. He extends a kind of non-anthropocentric world view.

Instinct is a psychological thriller, in which John Turtletaub examines the mind of an anthropologist, Ethan Powell who has been missing for a few years, living in the African jungles with the gorillas.He spent days and nights with them and was able to become a part of their group. The distance between him and the gorillas got reduced day by day. These herbivores lead a peaceful life in the jungle without obstructing the life of other animals. When the rangers came to shoot such innocent and harmless gorillas, he had no other way but to kill them for which he was confined to a psychic asylum. The act is highly symbolic and it reveals the non-anthropocentric view of Ethan Powell. He has only contempt towards those rangers for intruding in to the territory of the gorillas and for depriving them of their right to live. To express his protest, Powell resolves to remain silent and refuses to share his views with others. When the attempt to unlock his heart becomes a failure, the leading psychiatrist of the Psychic Asylum assigns the task to his upcoming young student, Theo Caulder who is an ambitious researcher in psychiatry and a spokesman of humanism. He considers professional excellence and fame as great achievements. His probing questions, promising assurances and curious searching eyes attract Powell to the doctor. Powell is thoroughly disillusioned by the way the world and humans have changed. He reduces the whole world into mere "takers" and "givers" where the powerful and the demanding takers incessantly exploit the powerless and take away everything from the givers leaving them dispossessed. He says that one will find more danger in one day in any city than one will ever find in those forests. Powell 
tells about how the hunters, tribals, gatherers and planters led a harmonious life with nature in primitive culture. They never killed more animals than they could use. They never ploughed more land than they needed. They fought, but never waged wars. They were a part of the world and used the resources judiciously. They never exploited the world the way modern man does. They never tried to impose their dominion upon the world. To Powell, the only thing we have to give up is our mad craze for power to establish dominion on earth. He shows great admiration towards primitive men who lived a life in harmony with nature. As George Sessions observes: "the cultures of most primal (hunting /gathering) societies throughout the world were permeated with nature- oriented religion that expressed the eco-centric perspective. These cosmologies involving a sacred sense of the earth and all its inhabitants, helped order their lives and determine their values." (Merchant 140)

Powell tries to make us aware that we have no right to establish dominion on earth. As Bill Devall observes, we are no kings here, nor gods but mere dwellers of this place. The world which has evolved through the ages is a dwelling place for all living beings. A new cosmic / ecological metaphysics which stresses the identity (I/ thou) of humans with non-human nature is a necessary condition for a viable approach to an eco-philosophy.....Man is an integral part of nature, not over or apart from nature. Man is a plain citizen of the biosphere, not its conqueror or manager. There should be a "democracy of all god's creatures" according to St. Francis; or as Spinoza said, man is a "temporary and dependent mode of the whole of God/ Nature."(Merchant 133). A vehement criticism of anthropocentrism and the urgent need to establish biological equality is underscored in the above cited observation.

Powell recalls the time he spent in the African forests along with the mountain gorillas. As the days passed,he became a part of their group.Powell was overwhelmed at the acceptance of a human being into a gorilla group.Deep in those forests away from everything he knew, everything he had been taught, he found peace, kinship and even safety. All these get dismantled with the entry of the greedy anthropos into their habitat and this intrusion forces Powell to kill the rangers

To Theo Caulder, the journey towards Ethan Powell became the journey towards the ungoverned man in the primitive state. With the help ofCaulder Ethan Powell realizes that freedom is not just a dream. It's there on the other side of the fence we build all by ourselves. Caulder's preconceived notion about a world which places humans at the centre completely gets dislodged after going through the process of change and education given by Powell. He emerges as a totally transformed man who has a heart enough to accommodate all creations of nature under the roof of 
mother Earth. The film implores human beings to go beyond anthropocentrism and to live in harmony with nature.

The domination of man over nature for fulfilling their selfish needs, the ecological imbalances caused by habitat destruction and reclamation of land for developmental activities have resulted in an ecological crisis and the Earth is slowly losing many of its dwellers. Actions that threaten the sustainability of ecology which create ecological imbalance are on the rise. The study aims to showcase a new paradigm that has to be formulated to reinstate an eco-centric earth where all living beings can enjoy equal freedom to live their life.

\section{References}

Davis, Tony. Humanism. London: Routledge, 1997. Print.

Defoe, Daniel. Robinson Crusoe. London: OUP, 1869. Print.

Ellis, H Frank, Ed. Twentieth Century Interpretations of Robinson Crusoe. London: Prentice Hall, 1969. Print.

Instinct. Dir. Jon Turtletaub.1999.Film.

Life of Pi. Dir. Ang Lee. 2012. Film.

Merchant, Carolyn, Ed. Key Concepts in Critical Theory: Ecology. Jaipur and New Delhi: Rawat, 1996. Print. 